\title{
Culture in its holistic and differential aspect, in anthropology and educational studies
}

\section{KEYWORDS}

culture, anthropology of education, ethnography of education, society, migration, cultural difference, multiculturalism, multicultural education

\begin{abstract}
In the present day, culture is a term which due to its complex nature, raises many theoretical and methodological questions. It is being perceived as something described more in plural terms rather than as a whole and a universal pattern, despite the impact made on the debate by the globalisation discourse. Therefore, it is presently an object of study in many academic disciplines. However, the discipline, which shows the most significant interest in the scientific investigation of culture, is anthropology. This paper examines the key issues in the understanding of culture within anthropology and its relation to pedagogy. The latter issue is being raised in order to highlight a relatively new anthropological subdiscipline, i.e. anthropology of education as a research perspective which could deliver certain answers to the problem of cultural diversity, multiculturalism, and multicultural education.
\end{abstract}

The omnipresence of culture is currently undeniable. Referring to culture, at times, constitutes a sine qua non condition for the description of the contemporary, significant human presence in particular areas of reality, both created by, and affecting the human being. Without the cultural rooting, the human omnipresence seems partial and shallow. Arguments for the significance of cultural factors add legitimisation to these descriptions, regarding the present humanist speculation. The somewhat metaphorically presented claim, at least regarding the very meaning of culture in various, especially academic, discourses, is legitimate. Culture becomes a specific narrative regarding the world; a peculiar language that creates reality using words. The reification of cultural terminology is a phenomenon, typical for numerous current models of academic description. Obviously, this somewhat optimist, regarding the culturological aspect, observation, applies to broadly defined humanities but in recent years we have noticed an increasing interest regarding the issue of the presence of cultural elements, processes and factors in areas remote from studies that explore the human in a strictly anthropological, i.e. social- 
-cultural context ${ }^{1}$. The proliferation of the issue of culture in studies has become a fact. Apart from its "overpresence" regarding the use of the very term in scholarly terminology, numerous studies, previously uninterested in the issue of culture per $s e$, have broadened their spectrum of research, including culture in their scope.

An increased focus on the research on culture, along with its practical manifestations occurring in various instances of human activity, is a phenomenon worth noting not exclusively due to a shaping of a new kind of scholarly discourse, with culture being its central point of interest. Nevertheless, the discourse determines the conceptualisation of culture today, both in the scientific and casual sense. The discourse partially takes place within the popular, broadly defined "new humanities" term including fields of study and trends that emerged in the ground of the transformation of Western thought, in the middle of the $20^{\text {th }}$ century. One could also note, that currently it is not a cultural discourse but rather a discourse on culture, or even further, a discourse via the subject of culture. Therefore, discourse is a specific metanarrative self-reflection, concerning the sources of our knowledge, and the ways of its articulation and application. Culture sometimes becomes an object of intense speculation, an object of epistemological longing, and an instrument allowing to break into realms that have locked their gates a long time ago, forcing us into the realm of naturalist and deterministic speculation. Culture, however, is often appropriated, instrumentalised and subjected to numerous acts of (ab)use in order to defend particular argumentation strategies included in politics, and used as a weapon in a series of symbolic wars. Despite the above entanglements, we begin to explain the world using culture although sometimes, its involvement in our attempts to create a complete multifaceted description of reality results in a severe failure. Despite that fact, we constantly and stubbornly undertake new efforts towards describing us as human beings via the presence of culture, regarding every aspect of our lives. Our bodies, the surrounding items and aspects of human existence, seemingly out of the scope of culture, are therefore culturally determined.

As I previously noted, the mentioned discourse along the years, has been increasingly emphasised on in scientific dissertations but also in journalist publications. In both cases regarding discourse, culture is used to describe issues that,

\footnotetext{
${ }^{1}$ The matter concerns discussions among biologists and zoologists, regarding complex protosocial behaviours, observed among various species of animals (not only primates). One should mention the research of bonobos conducted by a British primatologist Jane Goodall, as well as the research of brown rats conducted by an Israeli sociobiologist Joseph Terkel. The research results imply that we should consider culture as distinctive property of the human kind, as, in the above cases, e.g. the animals expressed an increased level of skill in creating and using tools.
} 
until recently, had not received much attention from the classical scholarly narrative, were regarded as fruitless by culture scholars, and considered insignificant for people and study groups. The matter discussed, regards issues that are a regular subject of scientific speculation, despite their highly "unscientific" nature. They are mostly included in the areas of contemporary culture, popular culture, everyday practice, and various consequences of globalisation processes. For example, scientific studies concerning phenomena in popular culture and their influence on identity, aesthetics and youth trends, are not considered an oddity, but instead treated as a serious research subject taught at universities. An increase in discussing such subjects is distinctive for numerous transformations taking place in the area of academic knowledge as well as the organisational culture and the institutional structures of universities. Universities are becoming a space for debates, discussions, and arguments, often initiated by circles that are non-academic, however significantly interested in introducing the aforementioned subject into a more official course of public debate. Scientific legitimisation of popular culture becomes a bottom-up postulate, formulated by individuals involved, i.e. people, groups, and institutions that create popular culture and act as the main area of its continuance.

The absorption of the term "culture" by everyday language and its articulation via social handbooks of everyday life, is an example of an all-encompassing distortion of the former understanding of culture, due to a mass inclusion of phenomena, processes and semantic fields, that until now, have not been regarded as cultural. Arguments for an elite culture or the historical immutability of high culture are being refuted today. Suffice to say, that a static understanding of cultural systems proves difficult today (considering the present day, one could pose a question whether it is even legitimate). In both aspects, scientific and casual, the term "culture" becomes simultaneously discursive and performative. Culture initiates particular debates as well as inspires activities (even if only in the realm of politics). A constant presence of culture in the main current of social debates, is in this sense, a factor, that significantly complicates the views on static cultural systems, regarding issues such as national culture, cultural and civilisation circles or tradition. Culture is no longer a monolith, that provided us with a collection of axioms, allowing us to construct our identities regarding, e.g. the ethnicity and territory. The world has become a specific global, cultural ecosystem, in the form of supranational relations and transnational forms of self-identification. Numerous commentators identify it as globalisation, as an inevitable progress of the tendencies of unification in the field of culture.

In the light of the above, the relations between the substantial individual and the abstract community, the subject and the object of historical narrative should 
be measurable and precise. Experience often proves otherwise. Such demands are made towards a field of cultural traditions, as national communities. However, according to social research, regarding the subject of, e.g. the sociological study by Jerzy Szacki on tradition, such requirements, regarding culture and cultural traditions, are completely unfounded. According to Szacki, tradition is an ideological construct, therefore naturalising it in public discourses is a utopian attempt. According to the Polish scholar, tradition is not history, although often treated as synonymous, a collection of tangible and empirically grounded facts. It is a social phenomenon that is subject to the same internal processes of change and the influence by external factors, as societies, including tradition. It provides societies with homogeneous and linear views, mythologising the past rather than explaining its constitutive facts. In the words of Szacki: "tradition not only simplifies and homogenises collective past, but it also highlights these aspects, that in the light of the available knowledge, appear to be simple and unequivocal" ${ }^{2}$. To treat thinking in terms of tradition, as a sort of an archaic, mythical outlook, would be a mistake however. According to the Polish sociologist both worlds, of tradition and of historiography, coexist in quite a complex symbiosis, with one prevailing over the other interchangeably.

The cultural variety is in this case an element that is permanent, but also characteristic for the dynamics characterising all human activity, constituting the creation and transformation in a given structural framework. The structural anthropology (partially also the poststructural anthropology with its various branches) would impart an almost scientific tone on the examination of aforementioned relations between the concealed order of nature and its external manifestations, making structuralism a formal and simultaneously complex and holistic method. In the light of the above, one should not wonder at the enormous popularity of structuralism, including various other disciplines in the 1960 s of the $20^{\text {th }}$ century. The idea presented by Claude Lévi-Strauss in his book Tristes Tropiques, that at the core of the enormous range of local articulations, lies a universal, however, well concealed order and an obscure logic of action, appeared as a revelation to many. Jean Piaget, one of the most ardent followers of Lévi-Strauss's thought (although applying it to psychology) describes the source of this phenomenon claiming that: "(...) once we focus on the positive content of the idea of structure, we come upon at least two aspects that are common to all varieties of structuralism: first, an ideal (perhaps a hope) of instrinsic intelligibility supported by the postulate that structures are self-sufficient and that, to grasp them, we do not have to make reference

\footnotetext{
${ }^{2}$ Szacki Jerzy, Tradycja, Warszawa 2011, p. 248.
} 
to all sorts of extraneous elements; second, certain insights; to the extent that one has succeeded in actually making out certain structures, their theoretical employment has shown that structures in general have, despite their diversity, certain common and perhaps necessary properties" 3 .

The formalism resulting from such an approach was highlighted with increased emphasis by another anthropological structuralist, i.e. Edmund Leach. In his, to a significant degree, postulative essay Rethinking Anthropology, the Cambridge mathematics graduate is exploring the possibilities of generalisation of kinship structures among examined Burmese Kachin people. Leach is cautious when making statements regarding arguments of other structuralists for the capability of a reconstruction of mentioned structures, drawing upon the fragmentary data on the outlook of cultural universals, and basing that effort on the comparative method. Cultural comparative studies are not identical with the right to create a generalisation of the general principles of culture in all its local and often differing variants. Attempts made earlier, i.a. by Alfred Reginald Radcliffe-Brown, to establish the framework of social structures, i.a. by comparing the family life and marriage principles among the inhabitants of Sub-Saharan Africa, are in his view, largely unfounded. Describing the variety of forms of culture, with the use of exact sciences terminology, leads Leach to a conclusion that "Considered mathematically society is not an assemblage of things but an assemblage of variables" Referring to topology as a branch of mathematical sciences, Leach is attempting, in contrast to more than just functional anthropologists like Radcliffe-Brown and Malinowski, to demonstrate the existence of principles behind creating normative generalisations without the flaws of the functional comparative studies, as in this (mathematical) meaning "functionalism in a mathematical sense is not concerned with the interconnections between parts of a whole but with the principles of operation of partial systems" ${ }^{5}$. As far as both types of approach, i.e. generalisation and comparison, are parts of the same scientific activity, his critique of functionalism, but also the overly "metaphysical" (as Leach would say later on) structuralism of Claude Lévi-Strauss, is filled with reluctance towards partial and fragmentary postulates of the strength of culture in its most general, and in this manner, fullest sense: as an instrument of systematising the environment in which human beings reside, the currents of history that influence the human beings and items, both material and spiritual, that human beings create. Therefore, the superiority of structural anthropology lies not only in its objective aspect, as culture has pre-

\footnotetext{
${ }^{3}$ Piaget Jean, Structuralism, 1971, pp. 4-5.

${ }^{4}$ Leach Edmund, Rethinking Anthropology, New York 1961, p. 7.

${ }^{5}$ Ibidem, p. 6.
} 
viously been an object of earlier speculation in the systematic sense, but also in the significant crystallisation of its methods and the applied language, which clarifies that in culture, which is universal, unchangeable and eternal. According to a clear statement by Leach, "generalisation is inductive; it consists in perceiving possible general laws in the circumstances of special cases; it is guesswork, a gamble, you may be wrong or you may be right, but if you happen to be right you have learnt something altogether new ${ }^{6}$.

To conclude on the structural approach towards culture, it is imperative to say that it was also filled with the belief in the necessity of extracting the essence of both the subject and the very discipline, from increasingly varying models of humanist cognition in the mid- $20^{\text {th }}$ century. Regarding the problem of a "rarefaction" of the theory and practice of ethnological research, pointed out by Lévi-Strauss, he turns back to the question of the method. Anthropological methodology was at the time (i.e. until the 1970s) established by a scheme determined by field research, especially the monographic research, i.e. focused on a complex description of a particular group's culture, repeated during long periods of time to grasp the potential dynamics of the research object and in result, to produce a better grounded theory and a more reliable knowledge. In both cases, to this day, the study of the the Trobriand Islands' communities, conducted by Bronisław Malinowski, is the main determinant of the standards regarding anthropological craftsmanship. It remains as such, even after publishing the Polish functionalist's diaries in 1967, which uncovered the real attitude and motivations hidden behind the Trobriand odyssey of field practice. The Polish scholar proves to be an ally to the French researcher claiming that, "striving for the discovery of general laws, that govern the cultural processes and shaping the reality of culture, is and will remain to be the scientific task of anthropology"'. A momentary attention should be directed to this unexpected alliance between structuralism and functionalism. However dramatically different in their principal theoretical premises, in terms of striving towards the discovery of the uncovering of the unchangeable rules behind culture, hidden behind ethnographic empirical evidence of terrain, both accounts represent similar determination. The analysis of terrain data allowed for drawing fundamental conclusions, concerning the emergence of certain regularities and rules from particular, the seemingly unrelated cases. As Edmund Leach notes: "The work of the social anthropologist consists in the analysis and interpretation of ethnographic fact, customary behaviour as directly observed. The most fundamental way in

\footnotetext{
6 Ibidem, p. 5.

7 Malinowski Bronisław, Jednostka, społeczność, kultura, Warszawa 2000, p. 239.
} 
which these procedures of modern anthropologists differ from those of their predecessors a hundred years ago is that the modern treatment of ethnographic evidence is always functionalist". This peculiar connection of striving for a synthesis with analytic speculation on the cultural reality observed with an anthropologist's eye, appears to lead to a capability of establishing a historical link with the work of his predecessors.

What is anthropology, considering the current tasks it is being challenged with? The question is, naturally, an attempt to tackle the contemporary problems mentioned before, along with its (post)modern distribution of emphases between individual worlds, drifting in a global network of connections, metanarratives, popular cultural reference variables and distorted patterns of identity. One should also add, that the form of the question may falsely suggest that the anthropology of culture possesses a fixed and unchangeable shape of its theoretical-methodological cognition framework. Regarding the discipline, such suggestion is an unfounded exploit and is deprived of its cognitive sense, in the context of the main object of anthropological studies. Conversely, one should differentiate between the homogeneous character of the research programme and the rich research traditions that diversify the anthropological thought regionally and historically. The latter, regarding anthropology, is set by the profound rooting in Western paradigms of social thought and philosophy. In that sense, they are dependent on changes that take place on the ground of scientific reflection forms, that differ from the anthropological perspective, and should be considered as parts of a broader view. Therefore, the roots of the interest regarding culture in social sciences, concerns not only the disciplinary beginnings of anthropology, but also the more profound philosophy of culture that spawned along with the change that occurred especially in Europe. Anthropological traditions regarding cultural research, are in many cases based on the pursuit of sketching out a world image via highlighting the enormous scale of colours, in which one could paint the behaviour of human beings, their collective life forms and their material products. Still, the variety of human cultures remains a certain raison dêtre for anthropology.

An undisguised and open fascination with the aforementioned variety of forms of existence is expressed in contemporary anthropological studies, on many levels. Nevertheless, each of them manifests a certain rooting of anthropological narratives in particular traditions concerning diversity. One of them relates to the ethnographic tradition in the sense of describing ethnic cultures via their characteristics subject to an objective description, e.g. their material culture. The

\footnotetext{
${ }^{8}$ Leach Edmund, Culture and communication, 1976, p.1.
} 
tradition determines the significant part of the foundation of Polish anthropological research, although its historical sources are placed in the early $19^{\text {th }}$ century research regarding folk culture, accomplished by German scholars tainted with the idealistic approach of their romantic philosophy. One should indicate the link, drawing upon the romantic ideals of, i.a. an indisputable and objectively existing, according to the followers of this intellectual approach, tie between the ethnic diversity of the world of human communities and its modelling, using the categories of kinship, race and biology. Consequently, for example, according to German experts in ethnography, including Alexander von Humboldt, cultural geography constituted an executive field for instruments well known to them. Comparative linguistics (the brother of Alexander, William also worked in this field), museum studies, and especially folkloristics; all the developing disciplines and fields of science were supposed to help the contemporaries realise, how distant the human being is from the ideal proposed by the Western, resident of Berlin and Dresden who is educated and aware of his superior place in the hierarchy of peoples. One of the major romantic thinkers of the discussed era, i.e. Johann Gottfried Herder, noticed this regularity and included it in his own vision of the philosophy of the aforementioned view.

On the other hand, the definition, regarded as classic today, formed in 1871 by Edward Tylor, however indicating at the particular areas of human activity, argued for the theory of cultural unity as a property immanent for the human nature. Regarding this matter, he formulates his own variant of uniformitarianism, postulating that culture and civilisation consist of numerous mutually dependent areas and creations of the human spirit. According to the evolutionary sociologist: "Culture or Civilization, taken in its wide ethnographic sense, is that complex whole which includes knowledge, belief, art, morals, law, custom and any other capabilities and habits acquired by man as a member of society. (...) the list of all the items of the general life of a people represent that whole which we call its culture.".

Tylor's definition, however methodologically and to a degree objectively obsolete, provides us with one more, pedagogically crucial thought, regarding the place of culture in human existence. He indicates the meaning of the process of acquiring culture via shaping of the skills, competencies and traits in an individual, that allow him to act in a socially (and culturally) affirmed functioning in wider communities. There is no difficulty in noticing, that this process of forming of individuals as members of larger social groups and the very society, is culturally determined to the same degree as all other types of content, listed in the defini-

\footnotetext{
9 Tylor Edward, Primitive Culture, New York 1871, pp. 1 et 8.
} 
tion and subjected to an intergenerational transmission. Regarding that fact, the discussed enculturation process, becomes the object of interest of various social science disciplines. Research conducted on the ground of anthropological studies, deserves significant attention. The anthropology of culture sets it as a fundamental factor for the forming of individuals as well as the perseverance of cultural systems, considered as internally integrated wholes of characteristic properties, internalised in individuals as values, symbols and cultural metaphors. It is a highly complex process, both regarding the diversity progressing with age and the differentiation of the process via diverse forms, adopted in different cultures ${ }^{10}$. Additionally, it is universal in human nature, the life experience and the adaptive activity of an individual regarding the social-cultural context in which the individual is functioning. In effect, enculturation comes into close proximity of socialisation and sometimes they are erroneously used interchangeably. As Margaret Mead noted, among others, such unsettling intellectual trend is present not only in the common practice of the term use, but also in scholarly works marked by the influence of psychologism, drawing upon a specific terminological uncertainty of a number of experts of such profession. In their works, the process of learning in its most general form is called simply socialisation ${ }^{11}$. The fact is, enculturation (similar to socialisation) encompasses the whole framework of an individual preparation for a cultural activity, and influences the patterns of the collective forms of cultural content transmissions.

Enculturation, being a significant process, is, according to anthropology, grasped as a process that is accomplished in and via social practice. It serves the "rooting" of individuals in the culture of a particular community, and further, as a secondary enculturation phase, as a critical reinterpretation and reevaluation of acquired skills of meaning and language competencies. To a lesser degree, it is an object of conscious (e.g. intellectual) speculation, to a higher degree it is, what is mostly passed on from generation to generation as the so-called "silent knowledge". The knowledge is a set of arranged patterns, indicating the framework of the boundaries of a socially accepted order and sketching a certain direction on the horizon, achieved by education of youth on values, norms, meanings, skills, etc. The importance of the perseverance of these patterns lies in the fact of the cultural system existence, however, the way in which the system is subject go change and is characterised by less centrally coordinated fluctuations of the creative and innovative activity of particular individuals, is of no less importance. That is why,

\footnotetext{
${ }^{10}$ Herskovits Melville J., Man and His Works, New York 1956, p. 40.

${ }^{11}$ Mead Margaret, Socialization and Enculturation, [in:] Current Anthropology, Vol. 4, No. 2 (Apr. 1963), p. 186.
} 
the three issues highlighted above: culture considered in a universal and differentiating aspect and the process of transmission, constitute the core of the speculation. They lead to the answer to the question regarding the essence of the research subject, of the two overlapping disciplines, e.g. anthropology and pedagogy. In my opinion, their overlapping semantic fields, the practices of use in selected scientific discourses and setting them into defined social paradigms, will allow not only for a fuller comprehension of how culture determines our activities and views. In a more distant perspective, it will allow for the establishing of an early definition of culture in the discourse regarding its relations with areas of social life, e.g. education. The established definition will become the ground for speculation regarding the overlapping of the problem of the cultural homo and heterogeneity in the context of using the cultural difference category, creating the theoretical basis for the idea of multiculturality and practical applications in the field of multicultural education.

The anthropological thinking on culture is expressing a belief, speaking of the necessity to cope with the heterogeneous nature of cultural reality, as well as the resulting fact of the inability of its full and unified cognition. A postmodern twist in the anthropology of culture along with similar transformational processes taking place in different fields of science up until the end of the 1970s of the $20^{\text {th }}$ century, contributed to that fact significantly. Similar to postmodernism in philosophy, postmodern anthropology is not (or was not) an integrated concept, a new holistic approach of an already known object, but, as different variants of humanist postmodernism, an intellectual twist forcing to undermine the current arguments for understanding culture as a certain whole. Works by James Clifford, George Marcus and Clifford Geertz, symptomatic for the postmodern thinking in anthropology, determined the framework of a new description of culture, as an object of a decentralised, multifaceted nature. Serving as a specific answer to the structural revolution inspired by Claude Lévi-Strauss and the symbolic approach by Mary Douglas and Victor W. Turner, the anthropological postmodernity attempted to constitute a line of criticism, as an equal methodological instrument for examining culture. According to the words by Melford Spiro, approaching the problem with significant reservation, the premise, crucial for the postmodernist perspective is: "its critique of science and the scientific method, a critique which it shares with (because it was borrowed from) postmodernist thought more generally"12.

\footnotetext{
12 Spiro Melford E., Postmodernist Anthropology, Subjectivity, and Science: A Modernist Critique, [in:] Comparative Studies in Society and History, Vol. 38, No 4, (Oct., 1996), p. 759.
} 
The popular disregard of contemporary anthropology towards a systemic apprehension of culture is no mere effect of a postmodern infusion with criticism as methodological criterion, but also (and possibly to a major extent) a result of changes that occur in the plane of cultural typography. The reconfiguration of an ethnic map regarding the intensifying transfer of people of the Western world towards the centre, i.a. in result of the consequences of the colonial history, is not the main concern here. It is also a result of a cultural hybridisation influencing local communities, regional groups or national societies. The hybridisation combines the previously non-uniform forms and content into a qualitatively new sort of cultural phenomena. The hybridisation is also a part (or a result) of complex global processes, that also occur in economical, political and social planes, regardless of still theoretical trends that shape the anthropological discourse in an academic sense, not yet recognised by the discipline. Globalisation, however defined at this level, is in itself an internally differentiated process. As far as humanist speculation regarding the subject, suggested the inevitable marking of the future with homogeneity of lifestyles (Zygmunt Bauman), economical and political arrangements (Francis Fukuyama) or ways of communication (Neil Postman), this premise is increasingly set aside in favour of accepting the heterogeneity of the aforementioned processes in regard of the local translations, transformations and the reinterpretations, accomplished from more than one, previously Eurocentric point of view. The category of the locality, the space, the boundary and according types of identity, returns clearly in the context of doubting the modern social project, grounded in the idea of the unifying progress.

Is, according to Alan Barnard, postmodernism a critique of modern ways of understanding culture ${ }^{13}$ Considering the thought, using cognitive categories, one should highlight, that indeed the majority of the movement's variants represented an epistemological criticism, whose tip was pointed at the current ideological order and the following social model, arising on the ground founded on this idea. While examining, in a broader perspective, this aspect of postmodernism, one could recall the words by Francois Lyotard, who does not express much optimism regarding the possibility and will of postmodernists to provide a better alternative for the old order saying that "it does not look as though they will be replaced, at least not on their former scale"14. The methodical denial of the "grand narratives" constituting the past and its contemporary continuation in different areas of social life are considered by the French philosopher, as a task of a fundamental

\footnotetext{
13 Barnard Alan, Antropologia, Państwowy Instytut Wydawniczy, Warszawa 2006, p. 226.

${ }^{14}$ Lyotard Francois, Postmodern Condition, 1987, p. 14.
} 
significance for the very task of critical deconstruction. The narratives constitute false promises of a better future, built on the ground of progress and the accumulation of scientific knowledge. The characteristic feature of modern illusions is the attachment to the systematisation, arrangement and classification of phenomena that constitute the fabric of reality. In terms of academic knowledge, it is related to creating particular intellectual paradigms, in social terms, to a feeling of belonging to a homogeneous collective, shared in communities, where social sense is clear and unequivocal. According to postmodernists, the open society in its teleological homogeneity, has never achieved that goal, or if the modernist social contract has been fully implemented and became a historically closed chapter, it appeared as riddled with internal conflicts and inconsistencies, generating a clear disturbance in the ideological and cultural continuum. The postmodernity overrules that belief, showing the fact, that social ties are in time, subject to erosion and even the most noble of ideals, subject to devaluation and degeneration. However, as Lyotard himself states: "(...) this point of view, it seems to me, is haunted by the paradisaic representation of a lost "organic" society"15.

Referring to the understanding of culture in the light of postmodern anthropology, or in a broader sense, understanding culture in regard of contemporary social sciences, one should note that in this context, it is not only subject to a specific "hyperparticularisation". The phenomenon is, as I mentioned previously, symptomatic for postmodernism, if only by the amount of possible variants of identity, proposed on the ground of this vaguely sketched out formation, regarding the changes of the Western cultural paradigm. Postmodernism, as a new paradigm in culture, is described in such manner by Scott Lash, who is shedding light on the consequences of this transformation in the realm of a semantic system ${ }^{16}$. What is even more important for the movement, is the treatment of culture as something created and used as a certain superstructure, established on the ground of history, politics or economics. The cultural determinism, well-established by the historical materialism, proves challenging for the traditional anthropological profession, due to its liquidity in a world of the global information circulation. The world has changed significantly in regard to its linguistic apprehension. Cultural statements are no longer internal adhesives for a particular system, defined by space and time, but are freed of these categories, while becoming ephemeral and ambiguous. Culture is experienced in a similar way, as it has become too frail of a fabric, to provide a safe haven for certainty, despite its direct relation to social

\footnotetext{
15 Ibidem, p. 15.

16 See: Lash Scott, The Sociology of Postmodernism, London 1990.
} 
activity. A known cultural ecologist, Marvin Harris states, that in the face of a postmodern humanist confusion, a combination of the concept of culture, both as an idea and an activity, allows for the linking of a holistic and a particular perspective regarding the problem. Moreover, the understanding of the process in which culture is transferred transgenerationally and supralocally provides us with a potential instrument of broadening the model, which caused culture to be defined as a strictly human property. The accounts, suggested earlier, surpassing the purely anthropocentric understanding of culture or the currently popular Transhumanism seem to acknowledge that observation. Therefore, Harris postulates, facing the posmodern scientific uncertainty regarding the procedure of the examination of culture, to promulgate a criticism based anthropology, however, at the same time, an anthropology that would overcome the doubt regarding the objective character of anthropological interpretation ${ }^{17}$.

How, in the face of a postmodern speculation, the dynamics that characterise the contemporary cultural condition, and is it possible to introduce new patterns? The cultural creativity is symptomatic for the humankind and is directly linked to the process of cultural transmission. Solon Kimball an American anthropologist, admits in the context of this thesis, that "among the characteristics that distinguish man from other forms of animal life is his capacity for culture" 18 . If, according to a psychologist Erik Erikson, human beings were considered to be social animals, than for a major group of contemporary cultural anthropologists, humans are a meeting place for determinants of differing natures. This fact, we as people, are given an extraordinary ability to transcend these determinants and create a specific order of culture, regarded as an effect of a continual process of learning and adaptation, e.g. regarding the environmental conditions or history. The innovative character of culture remains as a significant characteristic and manifests itself via different cultural inventions, reforms and revolutions, in the technological-applied as well as the symbolic aspect. This leads to a determination of a typical, in terms of anthropological theories and methodologies, presumption regarding the place and significance of the social actor in the process of either the cultural reproduction or the transmission of culture. The anthropological saying of "looking through the indigenous eyes" is a simultaneous placement of human activities in both planes of social research, i.e. subjective internal words and objective supraindividual structures. A similar presumption can be found outside of anthropology, e.g. as in

\footnotetext{
${ }^{17}$ Harris Marvin, Theories of Culture in Postmodern Times, Walnut Creek, London, New Delhi, 1999, p. 64.

${ }^{18}$ Kimball Solon, Culture and the Educative Process. An Anthropological Perspective, New York and London 1974, p 143.
} 
some accounts regarding the area of the philosophy of culture. A significant majority of these accounts fits into the area of the postmodern projection of emerging dominant ideological discourses and their following deconstruction. The denial by philosophical postmodernists of the methodological attachments regarding the traditions constitutive for research in the humanities and contributive, however unconsciously, to the metanarrative legitimisation of certain trajectories of power is in consequence doubted by other scholars, who study the problem of determining the general definition of culture, if only deprived of such connotations.

Undertaking such a task, the anthropological thought is encircling the issues of education, more or less taking over the object field, and sometimes even the narrative typical for pedagogical studies. However close these disciplines are in proximity, one must notice, that attempts at a bilateral cooperation of both groups, i.e. a broader exchange of theoretical-methodological views and perspectives in order to establish a common, transdisciplinary outlook, similar to the one that established the sociology of education as an independent subdiscipline between sciences, is a rare case ${ }^{19}$. Instead, there are noticeable attempts at presenting the issue of culture, its transmission and educational practices, leading to its perpetuation, from a point of view not of one of the aforementioned disciplines but particular accounts and theoretical schools both in pedagogy and in anthropology. The phenomenon most frequently includes the accounts that share the social-cultural criticism as a key methodological premise for the deconstruction of the process of forming of ideological orders (e.g. the critical pedagogy, mainly regarding Anglo-Saxon studies on education) or cultural patterns (e.g. the school of culture and personality as well as its anthropological derivatives). In both disciplines, the examination of individual experience in education is entangled in a their typical patterns of social-cultural syntheses of processes leading to the creation of the base of constructing collective identities, bonding systems, social and institutions of education, social roles, etc. This allows to suggest, that examining the matter of cultural transmission is in both cases bound by a specific appropriation of terminology; with the issue of culture being appropriated by anthropology, and the issue of learning and the transmission of cultural contents, appropriated by education sciences.

We can clearly determine the historical state of affairs, as in the field shaped in such a way, the debate regarding the education contexts in relation to the cultural transmission phenomenon, is being appropriated by anthropology and its vario-

19 Tooby John, Cosmides Leda, The psychological foundations of culture, [in:] Barkow Jerome H, Cosmides Leda, Tooby John (eds.) The Adapted Mind, Oxford 1992, p. 41. 
us particular branches. As the popularity of the term "culture" highlighted at the beginning of this chapter is attributed to contemporary humanities, the anthropological struggle with the cultural matter are inseparably tied to the ethnographic descriptive-coordinative tradition regarding the process of education in particular patterns of local cultures ${ }^{20}$. The cultural diversification of the enculturation phenomenon and its definition using the categories of particularism and relativism is mostly characteristic for Anglo-Saxon branches of the discipline and related to the foundations of anthropological knowledge established at the beginning of the $20^{\text {th }}$ century by Franz Boas and his students. According to classic authors such as Margaret Mead or Melville Herskovits, the education processes form the foundations of defined, internally integrated wholes, ascribed to human individuals, i.a. the internal structures of personality. The transmission of cultural content is accomplished by internalised human universes formed by the process of learning and acquiring new competencies in a framework of a particular cultural system. This leads to a situation in which the variety of forms and transmission pathways determines the very cultural variety. This rather simple kind of relations between the two planes of variety turns out to be essential for anthropological speculation regarding the basic cultural variety.

The transmission of cultural content, taking place in such systems may also reproduce dependencies specific and typical for a given system, e.g. social inequalities. That leads to a significant question: what kind of culture is subject to transmission? Is it a culture of the chosen (actually dominant) social classes, an unidentified whole of cultural models or maybe a number of cultural patterns, subjectively selected by certain individuals, that in the chaotic configuration of contemporality are more or less accidental and extemporary, rather than constant patterns that would encompass the entirety of human life experience? George and Louise Spindler raise questions of such character, regarding the issue of cultural transmission in the American context. Along with the denial of various forms of assimilation policies in the United States, with the Melting Pot idea becoming the most influential and lasting, the need to redefine the approach towards diversity and multiculturality emerged. Formal education plays an essential role in that matter, and American schools are widely acclaimed as instruments of transmitting the cultural patterns of white middle class ${ }^{21}$. Choosing an approach, at first conceptually similar to Pierre Bourdieu, and reconstructing the American social structure, George and Louise Spindler change their tone, focusing on the issue of social

\footnotetext{
${ }^{20}$ Whether they took an eager or a more critical approach is of no relevance.

${ }^{21}$ Spindler George, Spindler Louise, The American Cultural Dialogue and Its Transmission, Hampshire, Bristol 1990, p. 4.
} 
integration emerging from the situation of cultural diversity and taking a more postulative approach. The pragmatic approach towards the issue of education and the role of anthropology in understanding education is being narrowed down to the task of not only the analysis of ethnographic data, emerging from the research regarding education practice in schools and the situation of minorities in these institutions, as well as clarifying particular adaptive strategies of students that, in their educational experience, face the school system. Without disputing the details regarding these strategies, it is worth to enumerate them: reaffirmation, selective synthesis, segmentalisation, anomic withdrawal, biculturalism, constructive marginality and compensatory adoption ${ }^{22}$. The broad spectrum of situations, in which American minorities (especially African-Americans and Latin-Americans) establish a specific cultural reality in respect to the current education system, allows for grasping the cultural transmission, using categories based on the category of diversity in its ethnographic sense, i.e. those ascribed to the aspect of activity, creating an ideological and material reality and implying a necessity to prepare a scientific description of these two aspects.

As Roy Wagner highlighted, the creation of such fields of reality occurs, to a degree, naturally, causing culture to become identical with invention and innovation $^{23}$. The context, in which the cultural inventiveness is placed, may be subject (an it has constantly been) to changes resulting from a historical or even a systemic shift due to acculturation diffusion or simply the intercultural contact. Culture happens instead of simply existing. This common denominator can be ascribed to most accounts in anthropology and in other areas of social sciences, interested in a reconstruction of these dynamics. The factors of change, leading us to creating some new cultural artifact, are result of more than empirically available social phenomena, that is, if only secondarily, from the change occurring in the semantic plane. The economical crisis in banking, the wider access to information technologies, a campaign by a particular political party, depend on the way people comprehend the semantic phenomena carried by these instances. Here, the category of difference is also noticeable because just as people find themselves in varying economical situations, possess varying access to technology and vote for different political parties, they also have varying levels of comprehension regarding the causes and consequences of their activities. Therefore, the transformations occurring in the symbolic realm affect in the broad sense, the recomposition of the whole system of culture due to the fact that culture is an internally unified communica-

\footnotetext{
22 Ibidem, p. 79.

23 Wagner Roy, The Invention of Culture, Chicago, London 1981, p. 34.
} 
tion system. Wagner presents a similar position, saying that: "All human thought, action, interaction, perception, and motivation can be understood as a function of the construction of contexts drawing upon the contextual associations of symbolic (semiotic) elements. Since all such action, whether effective or ineffective, good or bad, "correct" or "incorrect" is developed through successive constructions, its generation can be described as "invention" or "innovation"”" 24.

Just as ethnography, in the traditional sense of the word, is currently defined by scholars as an effort drawing upon a specific methodology (it may be and is often considered as an ethnographic method applied to different social sciences) implemented in the field or as a scholarly activity drawing upon the very act of describing the cultural empirical evidence, and via such actions, simultaneously contributing to that data (e.g. according to Clifford Geerts), so ethnography of education can be considered as a specific system of social science practices applied to the aforementioned two realms of education. The goal of this specific branch of knowledge regarding culture and education is "to provide rich, descriptive data about the contexts, activities, and beliefs of participants in educational settings" 25 . Generally speaking, such data represents processes of education in their practical aspects, i.e. in the light of their actual placement in the social situation or education institution, available for examination. Only after being equipped with the anthropological significance, the data can be related to a specific theory of culture emerging from its interpretation and can be a part of a broader insight into the cultural senses carried by the realm of education ${ }^{26}$. One should also indicate, that first, such an attachment of ethnography to empirical evidence does not lead to a postulate of a research criticism, appropriate for the sociology of education, exercised in the spirit of positivism and functionalism, and second, that the field research practice unveils that such an approach, objectifying of other cultural contexts, is unfounded due to its constant ethnocentric attitude. The transfer of speculation regarding culture in the field of a humanist metanarrative and the debate on the nature of its objective cognition, significantly broadens our anthropological understanding of the phenomenon, leading us to perceive it rather in terms of potentiality than an imperative. According to Pierre Bourdieu (although he spoke of his understanding of the term "ethnology"): "It is significant that "culture" is sometimes described as a map; it is the analogy which occurs to an outsider who has to find his way around

\footnotetext{
${ }^{24}$ Ibidem, p. 38.

${ }^{25}$ Goetz Judith P., LeCompte Margaret D., Ethnography and Qualitative Design in Educational Research, London 1984, p. 17.

${ }^{26}$ I shall expand on this thought in the following parts of this book, where I shall explain in more detail both the ethnography of education and the anthropology of education phenomena.
} 
a foreign landscape and who compensates for his lack of practical mastery, the prerogative of the Native, by the use of a model of all possible routes"27.

If we are capable of undertaking an ethnographic mission as an activity drawing upon the direct field experience and being the effect its description (or a pure "producing" of a text), then while speaking of education, we as participants of such an analytical procedure, are simultaneously required to apply a specific type of imagination, allowing us to fuse the base data into a more complex cultural framework. The formula of ethnographic imagination proposed by Paul Willis, provides a certain solution to the problem of changes presently occurring in the regard of the term "culture" and the transformation of its dominant patterns, that I sketched out in the hereby chapter. Willis, an advocate of the said type of imagination appears as one of the "sociologists of the night", defined by Alain Tourain as "those who listen to the ones who cannot speak for themselves anymore" and "exploring the enormous world of "exclusion"'28. He too is acknowledging the change in social relations, being the consequence of modernism, as a factor demanding a dramatic change of approach towards the object of our speculations, and so in this case, the cultural reality that transgresses the boundaries of the former scientific language. According to the British scholar, ethnographic imagination should allow for a presentation of the relations between at least three elements. According to Willis, the set of elements consists of the "creative meaning-making in sensuous practices; the forms, i.e. what the formed and forming relation to the main structural relations, necessities and conflicts of society" ${ }^{29}$. Therefore, the creation of the cultural identity may be regarded as a process, and its material consequences may be described in a fuller and livelier sense, according to the lively nature of cultures, studied by anthropologists and other social scholars, who are rarely capable of grasping its dynamics, especially regarding the rapidly emerging and passing youth subcultures. In his other work, the Profane Culture, provides this vision, deprived of illusion, with a more profound meaning, stating that "Real events can save us much philosophy" ${ }^{30}$ and that the social sciences "could never produce a bedizened, solid motor-bike, an embroidered sheepskin coat, an outrageous rock ' $n$ ' roll record." ${ }^{31}$. According to Willis, the process of culture creation is presently the place of a semiotic excitement, and the major meanings are being tackled and reinterpreted. This carries our attention towards the culture of particular social classes and how

\footnotetext{
27 Bourdieu Pierre, Outline of the theory of practice, , 1977, p. 2.

28 Touraine Alain, O socjologii, Warszawa 2010, p. 52.

29 Willis Paul, Ethnographic Imagination, 2000, p. 109.

30 Willis Paul, Profane Culture, Princeton 2014, p. 1.

31 Ibidem, p. 3.
} 
the given culture tackles or perpetuates certain orders, e.g. socialising the working class youth so that they share particular preferences, tastes and in consequence, a position in the British society.

The analysis, conducted by Paul Willis in his book titled Learning to Labor, carefully unveils this method of application of the ethnographic imagination regarding class cultures ${ }^{32}$. One cannot overemphasise on the role of the ethnographic method in this description. The complex research, conducted by Willis in the 1970s in Hammertown, England, unveils the key to the reproductive processes of the stratification of its working-class quarter residents as well as the cultural creation, by children and youth in working-class families, specific senses related to everyday activities, items and school space. Drawing upon qualitative methodology, the research renders quite surprising results, considering the fact that this period of British social sciences, was characterised by a clear rupture, due to the denial, by a number of scholars, of the culture of the sociological tradition (e.g. functionalist) that demanded the study regarding great social institutions, and in turn, directing towards phenomena such as the increasingly growing British popular culture, which increased in momentum and energy as a reforming factor. It allows to understand, how social exclusion in this particular context, applies as a cultural mechanism, and the scholars' genuine attention drawn towards people functioning de facto at the margins of the British society, constitutes a significant element adding to the ethnographic context, but is also a sort of social engagement, in order to change the situation ${ }^{33}$. It is not unusual, that as one of the main advocates of the birth of cultural studies, described at the beginning of this chapter, Willis maintains a serious approach towards matters, that are important and essential for the working-class youth, e.g. regarding identity, therefore, valuing the same things, that are valued by his respondents. The lively, sometimes even vulgar language used by his interlocutors, seemingly unveils the essence of the problem, i.e. the perpetuation of social marginalisation via education, in which a given, intergenerationally transmitted language also plays a culture-forming role. School becomes a field, in which social senses are being created, i.a. in language, by working-class children as an opposition and rebellion against the hegemony of the upper classes, e.g. represented by the teachers.

\footnotetext{
32 One would contrarily add, that the formulation has a two-fold meaning, i.e. cultures of given social classes and cultures of school in class as micro-societies, reflecting the social relations in a broader sense.

${ }^{33}$ Angrosino Michael V., Obserwacja w nowym kontekście. Etnografia, pedagogika i rozwój problematyki społecznej, [in:] Denzin Norman K., Lincoln Yvonna S. (eds.) Metody badań jakościowych, Warszawa 2010, p. 143.
} 
The Hammertown case gives reason to assess, that the schools presented by Willis, become places of a cultural clash of two different cultural orders, therefore, generating a new quality, as a practical result of this struggle. On one hand, we have the typical British attachment to class distinctions (or, according to Kate Fox, typically British language class $\operatorname{codes}^{34}$ ), while on the other, the constant attempts at breaking of existing social barriers, i.a. through humour, which in a strongly masculine student environment also forms sexism and racism. Willis is aware of this dichotomy, by differentiating the forms of the cultural creation process, into a class culture and an institutional culture. Class culture may be considered as a certain response to the activity of institutions such as schools, because, according to Willis, a phenomenon he calls differentiation, is made visible here. What is the nature of this differentiation? Differentiation is "the particular process by which working class culture creatively manifests itself as a contrete form within, and separates itself from even as it is influenced by, the particular institution"35. Differentiation is a process "whereby the typical exchanges expected in the formal institutional paradigm are reinterpreted, separated and discriminated with respect to working class interests, feelings and meanings" ${ }^{\prime 36}$. The school in Hammertown becomes a laboratory, where the ethnographic knowledge, along with the scrupulous and long-lasting examination of social and cultural practices, serves to measure the tensions that create a qualitatively new "school counter-culture", which in its own sense, denies the legitimacy of the said institution's paradigm.

In the worlds of William Dilthey, we can say, that "various kinds of expressions, related to the differences in life stances occur in the lived experience" ${ }^{37}$ and that "the endless variety of life expands in individual lives of particular people, as they relate to the environment, the other people and artifacts"38. Not only Dilthey noticed the relation and the mutual influence of humanities and life experience. Anthropology as a human science makes an obvious attempt at presenting these relations and their direct cultural results. The phenomenon of education is indisputably one such result, providing the cultural process with a specific and an ethnographically accessible shape in the forms of education and education institutions. Both fields of research, formerly enviously guarded by the sociology of education, are not exactly new to anthropological studies, but resemble an old friend, who

\footnotetext{
34 See: Fox Kate, Przejrzeć Anglików. Ukryte zasady angielskiego zachowania, Warszawa 2008.

35 Willis Paul, Learning to Labor. How Working Class Kids Get Working Class Jobs, New York 1977,

36 Ibidem.

37 Dilthey Wilhelm, Budowa świata historycznego w naukach humanistycznych, Gdańsk 2004, p. 93.

38 Ibidem, p. 95.
} p. 62 . 
returns after a period of absence. The acquaintance is significant as anthropology does not propose to offer the ground for the evaluation of the activities of schools, as institutions exercising their particular tasks, but to unveil their essence, as a specific space and place that is both culturally determined, and culture-creating ${ }^{39}$. The specifics of education sometimes take the form of articulations, would be placed in the categories such as school subcultures, competence deficiency, development disorders and social marginalisations, by other disciplines. Giving voice to people subjected to the processes of education, the study regarding the human allows us to look at the pathway, through which the culture is transferred and change in the perspective of experiencing education and generating particular cultural responses in its regard. Enough to say, that the symptomatic property of this phenomenon, determining such reactions, is their increasing variety, particularly visible in multicultural societies.

\section{References}

Angrosino Michael V., Obserwacja w nowym kontekście. Etnografia, pedagogika i rozwój problematyki społecznej, [in:] Denzin Norman K., Lincoln Yvonna S. (eds.) Metody badań jakościowych, Warszawa 2010

Barnard Alan, Antropologia, Państwowy Instytut Wydawniczy, Warszawa 2006

Bhabha Homi K., Miejsca kultury, Kraków 2010

Blom Jan-Peter, Ethnic and Cultural Differentiation, [in:] Barth Frederik (eds.), Ethnic Groups and

Boundaries. The Social Organization of Culture Difference, Scandinavian University Books, Oslo, London 1969

Bourdieu Pierre, Outline of a Theory of Practice, 1977.

Goetz Judith P., LeCompte Margaret D., Ethnography and Qualitative Design in Educational Research, London 1984

Harris Marvin, Theories of Culture in Postmodern Times, Walnut Creek, London, New Delhi 1999

Dilthey Wilhelm, Budowa świata historycznego w naukach humanistycznych, Gdańsk 2004

Fox Kate, Przejrzeć Anglików. Ukryte zasady angielskiego zachowania, Warszawa 2008

Herskovits Melville J., Man and His Works, New York 1956

Ingold Tim (ed.), Key Debates in Anthropology, London and New York 1996

Kimball Solon, Culture and the Educative Process. An Anthropological Perspective, New York and

London 1974

Lash Scott, The Sociology of Postmodernism, London 1990

Leach Edmund, Culture and Communication, 1976

Leach Edmund, Rethinking Anthropology, New York 1961

Lévi-Strauss Claude, Antropologia strukuralna II, Warszawa 2001

Lyotard Francois, Postmodern condition, 1987.

39 Wax Murray L., Wax Rosalie H., Great Tradition, Little Tradition and Formal Education, [in:] Wax Murray L., Diamond Stanley, Gearing Fred O. (eds.), Anthropological Perspectives on Education, New York, London 1971, p. 8. 
Malinowski Bronisław, Jednostka, społeczność, kultura, Warszawa 2000

Mead Margaret, Socialization and Enculturation, [in:] Current Anthropology, Vol. 4, No. 2 (Apr. 1963)

Piaget Jean, Structuralism, 1971.

Spindler George, Spindler Louise, The American Cultural Dialogue and Its Transmission, Hampshire, Bristol 1990

Spiro Melford E., Postmodernist Anthropology, Subjectivity, and Science: A Modernist Critique, [in:] Comparative Studies in Society and History, Vol. 38, No 4, (Oct., 1996)

Szacki Jerzy, Tradycja, Warszawa 2011

Tooby John, Cosmides Leda, The psychological foundations of culture, [in:] Barkow Jerome H, Cosmides Leda, Tooby John (eds.) The Adapted Mind, Oxford 1992

Touraine Alain, O socjologii, Warszawa 2010

Turner Terence, Anthropology and Multiculturalism: What is Anthropology That Multiculturalists Should Be Mindful of It?, [in:] Cultural Anthropology, Vol. 8, No. 4, (Nov., 1993)

Tylor Edward, Primitive Culture, New York 1871

Wagner Roy, The Invention of Culture, Chicago, London 1981

Wax Murray L., Wax Rosalie H., Great Tradition, Little Tradition and Formal Education, [in:] Wax Murray L., Diamond Stanley, Gearing Fred O. (eds.), Anthropological Perspectives on Education, New York, London 1971

Willis Paul, Learning to Labor. How Working Class Kids Get Working Class Jobs, New York 1977

Willis Paul, Profane Culture, Princeton 2014

Willis Paul, Ethnographic Imagination, 2000 